\title{
GAMETOPHYTE AND SEX ORGANS OF REBOULIA HEMISPHAERICA
}

CONTRIBUTIONS FROM THE HULL BOTANICAL LABORATORY 276

ARTHUR W. HAUPT

(WITH TWENTY-ONE FIGURES)

The Marchantiales represent a very natural group of liverworts whose evolutionary tendencies are more obvious and striking than those of any other order of Bryophytes. The characters which distinguish them from the Jungermanniales are remarkably constant, and yet the structural changes which one meets in passing from the lower to the higher forms are represented by an almost complete series of intergrades. In order to determine the phylogenetic relationships of the little investigated genus Reboulia, the present study was undertaken.

According to SchIFFNER (7), Reboulia comprises ,2 species: one confined to Java, and the other, $R$. hemisphaerica, a polymorphic species, cosmopolitan in distribution. STEPHANI (9) recognizes only $R$. hemisphaerica as a single polymorphic species, including as synonyms several other forms which various authors have raised to specific rank. CH. and R. DouIN (3) have described 2 new species from France and other parts of Europe which they have named $R$. occidentalis and $R$. Charrieri. These are distinguished from $R$. hemisphaerica chiefly on the basis of the size and wall markings of the mature spores, the size and number of lobes of the female receptacle, and the position and behavior of the male receptacle. The latter forms two groups which come to occupy marginal positions on the thallus instead of remaining undivided and median as in $R$. hemisphaerica. The writer has observed this in rare cases in $R$. hemisphaerica, and if the small size of certain parts be explained on the basis of impoverished vegetative conditions, there seems to be little justification for the establishment of these 2 new species.

ScHIFFnER (7) divides the Marchantiaceae into the 3 subfamilies, Corsinioideae, Targionioideae, and Marchantioideae. 
Following Leitgeb (6), he further separates the Marchantioideae into the Astroporeae, Operculatae, and Compositae. Cavers (2) has shown that the characters which separate these groups are not entirely constant; yet he recognizes their individuality, but elevates them to the rank of families and renames them Cleveaceae, Aytoniaceae, and Marchantiaceae. Reboulia belongs to the Operculatae of Leitgeb or to the Aytoniaceae of Cavers.

\section{Material}

The writer is indebted to Dr. W. J. G. LAND for the material used in this investigation. Four collections were made by him over a period of ro years during the months of September, October, and November at Rome, Indiana. A few of the slides were made by Mr. S. A. Ives, but most of them were prepared by the writer.

\section{Thallus}

The gametophyte plant body of Reboulia hemisphaerica is a pale green, dichotomously branched thallus with slightly undulate margins and a distinct midrib. Rhizoids and scales arise from the ventral surface. Both smooth and pegged rhizoids occur, their ends often being highly contorted when in contact with soil particles. The dark red ventral scales are 2 -ranked and point diagonally forward and outward. They do not arise from the splitting of a single scale as in most species of Riccia, but are separate from the beginning. The scales are I cell thick except near their place of attachment to the thallus where they are often 2 cells thick. They are unappendaged.

The body of the thallus is differentiated into a lower colorless region of compact elongated cells with rather thick walls, and an upper region of loose chlorophyllose tissue containing large air chambers. Intracellular fungi live in the lower region (fig. 5). The walls of the epidermal cells are slightly thickened and are devoid of chloroplasts except near the growing point of the thallus (fig. 2). The plastids in the air chamber region are rather large and contain several starch grains with distinct hila. Plastids in the cells in the growing region are small and contain no starch. The development of the large starch-producing plastids was 
studied, and a series obtained as illustrated by fig. $6 a-d$. Small oil globules are very abundant in the apical cell region and occur less abundantly in the cells of the older parts of the thallus. The
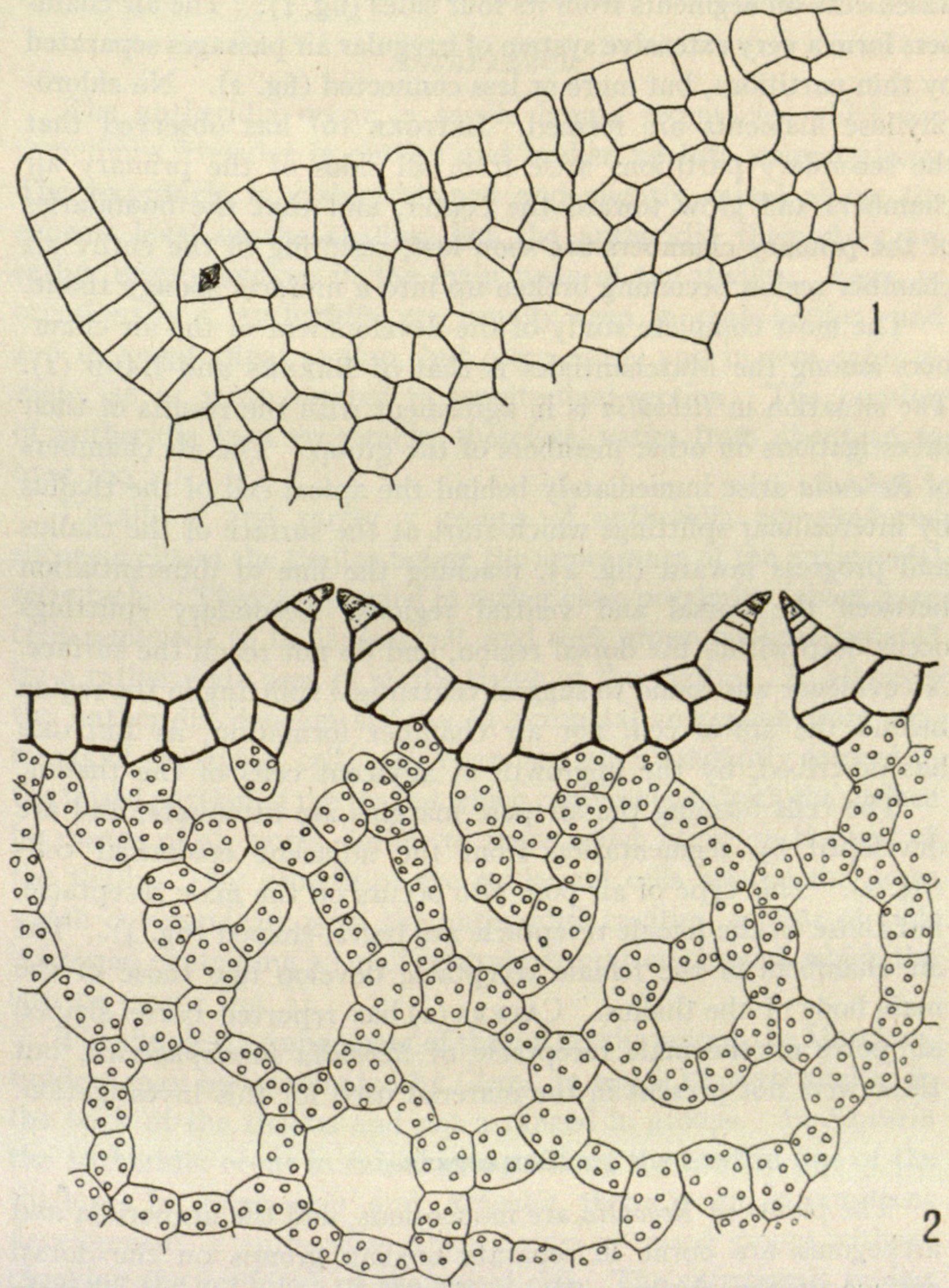

Figs. I, 2.-Fig. I, apical cell of thallus and young air chambers, $\times_{47}$; fig. 2 , upper region of thallus showing air chambers and pores, $X_{250}$. 
formation of a definite oil cell from an ordinary vegetative cell is a common feature of the genus. No gemmae are produced.

The thallus grows by means of a single cuneate apical cell which cuts off segments from its four sides (fig. I). The air chambers form a very extensive system of irregular air passages separated by thin partitions, but more or less connected (fig. 2). No chlorophyllose filaments are formed. Leitgeb (6) has observed that the secondary partitions arise from all sides of the primary air chambers and grow toward the center, and that the boundaries of the primary chambers are soon lost, resulting in the entire air chamber region becoming broken up into a uniform spongy tissue.

The most complete study of the development of the air chambers among the Marchantiales is that of BARNES and LAND (I). The situation in Reboulia is in agreement with the results of their investigations on other members of the group. The air chambers of Reboulia arise immediately behind the apical cell of the thallus by intercellular splittings which start at the surface of the thallus and progress inward (fig. I), reaching the line of differentiation between the dorsal and ventral regions. Secondary splittings occur deep within the dorsal region, and do not reach the surface. No evidence was found to suggest centrifugal splitting in the region behind the apical cell, nor air chamber formation, as LEITGEB has described, by the upgrowth of adjacent cells of the thallus.

The cells forming the air pore margins are attenuate, and are developed by segmentation from the adjacent epidermal cells (fig. 2). This type of air pore also occurs on the male receptacle, but those on the female receptacle are barrel-shaped (fig. 4). The air chambers in the female receptacle develop like those of the main body of the thallus. CAvERS (2) has reported barrel-shaped air pores on the male receptacle of Reboulia hemisphaerica, but these were not present in the material used for this investigation.

\section{Sex organs}

The plants of Reboulia are monoecious, and the antheridia and archegonia are borne in separate median groups on the dorsal surface of the thallus. The antheridial group is only slightly raised above the general surface of the thallus, and the archegonial 
receptacle becomes lifted up on a stalk only after the sporophytes are approaching maturity. The archegonia appear in the autumn, fertilization occurs, and the embryo develops immediately. The sporophyte, however, does not mature until the following spring.

\section{ANTHERIDIUM}

The antheridia occur in sessile lunate receptacles which are sometimes irregular in outline and broken up into several pieces. The receptacle is cushion-shaped and slightly raised above the general level of the thallus, but the antheridia themselves are rather deeply sunken in the main body of the thallus. Four, or occasionally 5 , antheridia are usually seen in cross-section, and 4-6 in longitudinal section, but often more, and in rare cases as many as 24 were counted in longitudinal section. The number of antheridia in a receptacle, therefore, varies from about 16 to over Ioo.

Usually 2 and rarely 3 groups of antheridia are produced successively on the thallus before the appearance of the archegonial receptacle. They are formed in rather close proximity (about 7-ro cells removed) to the apical cell, and each group becomes isolated by a rather wide area of sterile tissue of the thallus. In all cases the antheridia develop strictly in acropetal succession from segments of the apical cell. Air chambers are abundantly formed in the raised portion of the thallus which communicate with the surface by means of air pores similar to those which occur on the rest of the thallus. By growth of the epidermal cells around the pores which communicate with the antheridial cavities, a plate of cells is formed containing a small central perforation through which the sperms escape (fig. 3).

The simplest arrangement of the antheridia among the Marchantioideae may be represented by Clevea, in which they are sunken in the back of the thallus and not arranged in groups. In Sauteria the antheridia occur in raised groups along the median line of the thallus. In Fimbriaria and Reboulia there is an intermittent development of antheridia, which occurs in raised groups without checking the activities of the apical cell. The situation is similar in Aytonia (Plagiochasma), except that the apical cell does not 
function while the antheridial group is developing, but later continues the growth of the thallus. In Dumortiera the antheridial receptacle is lifted up on a short stalk and represents a definite branch system which terminates apical growth of the thallus. In Marchantia the situation is similar, but the stalk is long.

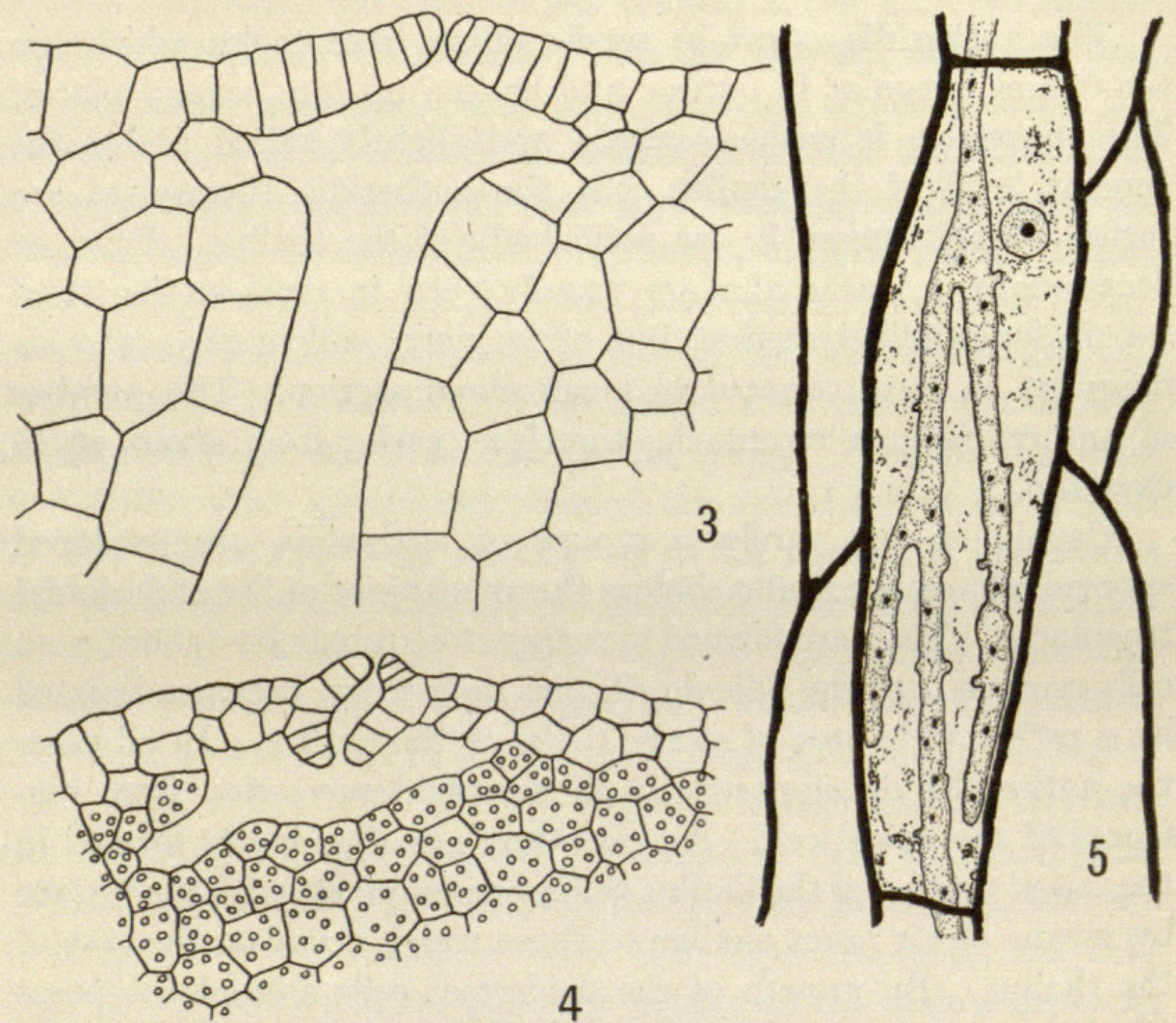

Figs. 3-5.-Fig. 3, pore on male receptacle through which sperms escape, $\times_{470}$; fig. 4 , air chambers and pore in female receptacle, $\times_{25}$; fig. 5 , cell from ventral region showing intracellular fungus, $\times 470$.

The development of the antheridia of Reboulia is similar to that of the other Marchantiales which have been investigated. The superficial papillate initial is soon overgrown by the adjacent cells of the thallus, so that the antheridium comes to lie in a pit; the development of the antheridial pit is therefore very different from that of the air chambers. The first division of the initial is transverse and separates the imbedded portion of the stalk from the rest of the antheridium (fig. 7). Additional transverse walls 
appear in the outer cell without a definite sequence, resulting in a filament of 4 cells (fig. 8). Vertical walls are then formed in two planes at right angles to each other, which usually are first developed in the basal tiers, or sometimes elsewhere (fig. 9). After the formation of the first vertical walls in the lower tiers, additional transverse divisions usually occur below, and as a consequence 5 or 6 tiers of cells are formed (fig. Io).

In Marchantia polymorpha STRASBURGER (I0) has reported that the 3 transverse walls in the outer cell appear in centrifugal succession, although he shows no mitotic figures to prove this. Fig. 8 suggests that

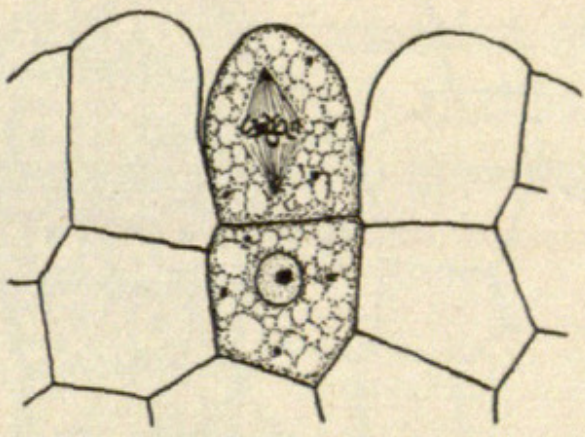
this may occur in Reboulia. STRAsBURGER has also shown that the vertical walls appear in the 4-celled stage, but that no additional transverse walls are formed until the wall

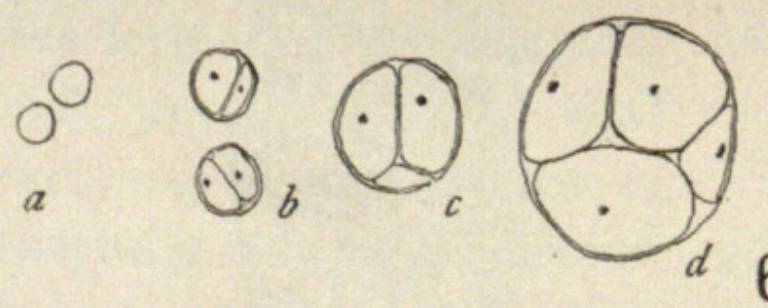

6

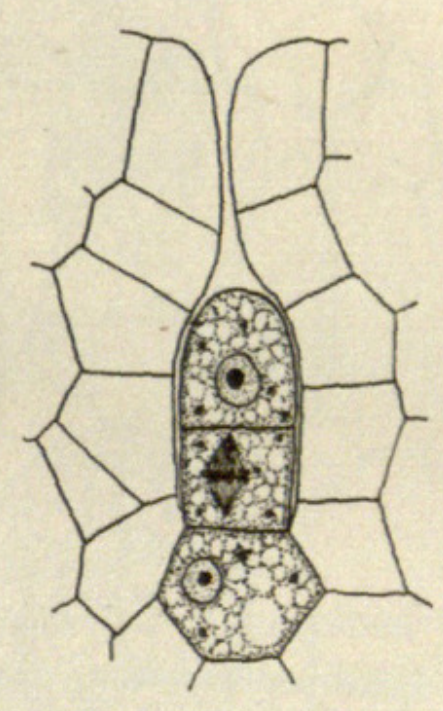

7

8

Figs. 6-8.-Fig. 6, series showing development of starch grains in plastids, $\times 1850$; fig. 7 , first division of outer segment of antheridial initial, $\times 790$; fig. 8 , division of the lower segment of the outer cell, $\times 79^{\circ}$.

and spermatogenous cells are differentiated. Marchantia therefore seems to be somewhat more advanced in this respect. DURAND (4), however, who also studied $M$. polymorpha, has found that additional transverse walls may follow the appearance of the vertical walls, but in no observed case did he find that they preceded the first vertical walls.

Periclinal divisions next occur invariably in the 3 uppermost tiers of cells (figs. II $\mathrm{I} 3$ ), separating the inner spermatogenous cells from the outer sterile wall cells. The cells in which no periclinal appears form the stalk. The further development of the 
spermatogenous tissue is like that of the other Marchantiales. The sperms differ in no way from those of the other members of the group.
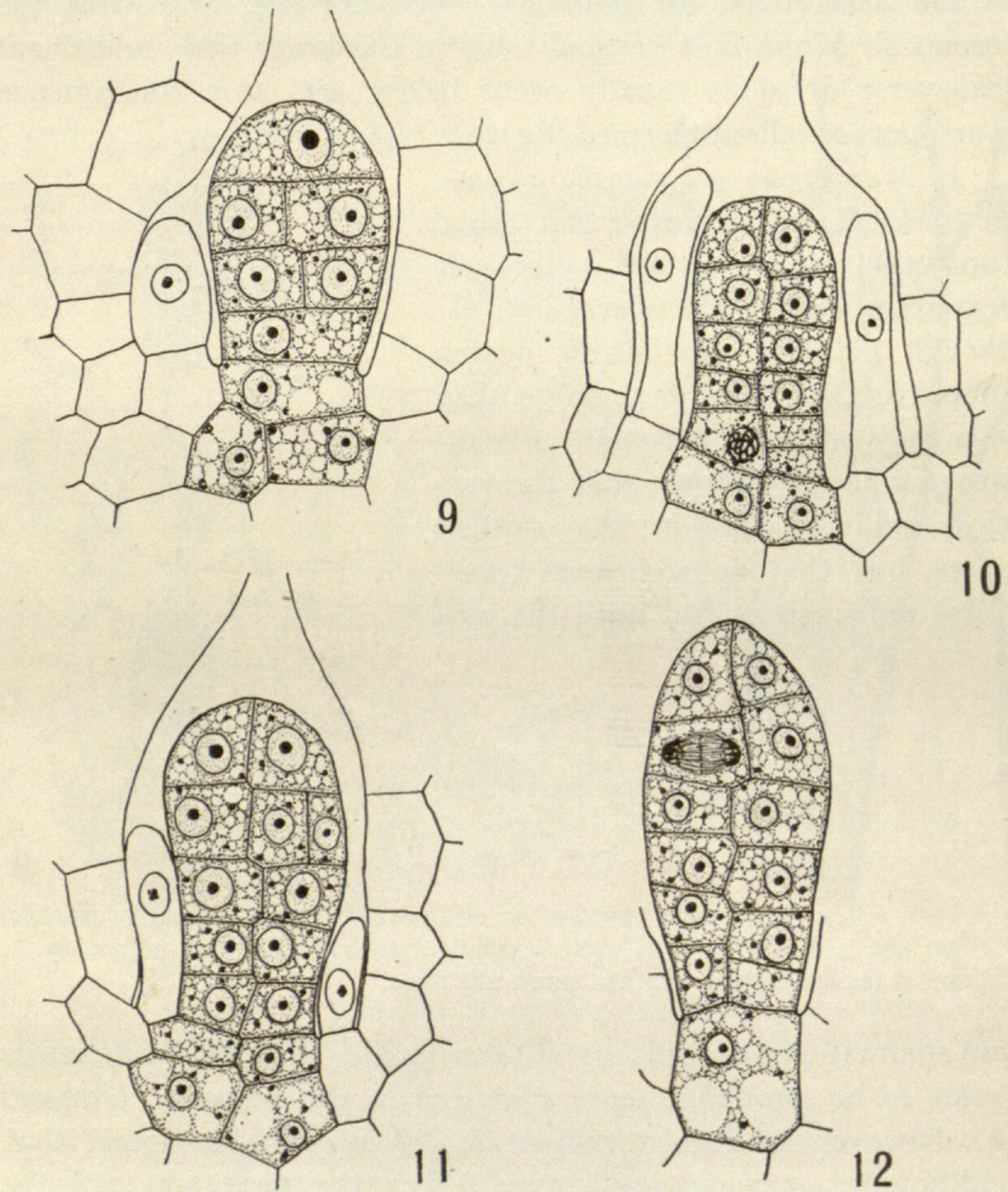

Figs. 9-1 2.-Older antheridia: fig. 9, vertical walls appearing in middle tiers, $\times 790$; fig. ro, complete development of vertical walls and appearance of transverse walls below, $\times 790$; figs. II, I2, appearance of periclinal walls, $\times_{790}$.

With the coming in of the first vertical walls in the young antheridium, several mucilage hairs arise from the cells which line the antheridial cavity. These arise near the base of the 
antheridial stalk as I-celled, slightly elongated structures with a nucleus and a highly vacuolated cytoplasm (figs. 9-I3). They elongate considerably and secrete abundant mucilage around the mature antheridia.

\section{Archegonium}

The archegonia are borne on receptacles which arise as domelike areas at the growing point of the thallus. The formation of the archegonial receptacle involves the apical cell of the thallus, so that growth for the season is checked. Several (up to 6) growing points are organized in the young receptacle from segments of the main apical cell of the thallus, and thereby a new apical cell is formed in each receptacle notch.

In the simpler Marchantioideae, as in Clevea and. Aytonia, the main apical cell of the thallus is not involved in the formation of the archegonial receptacle, so that several successive groups of archegonia may be formed on

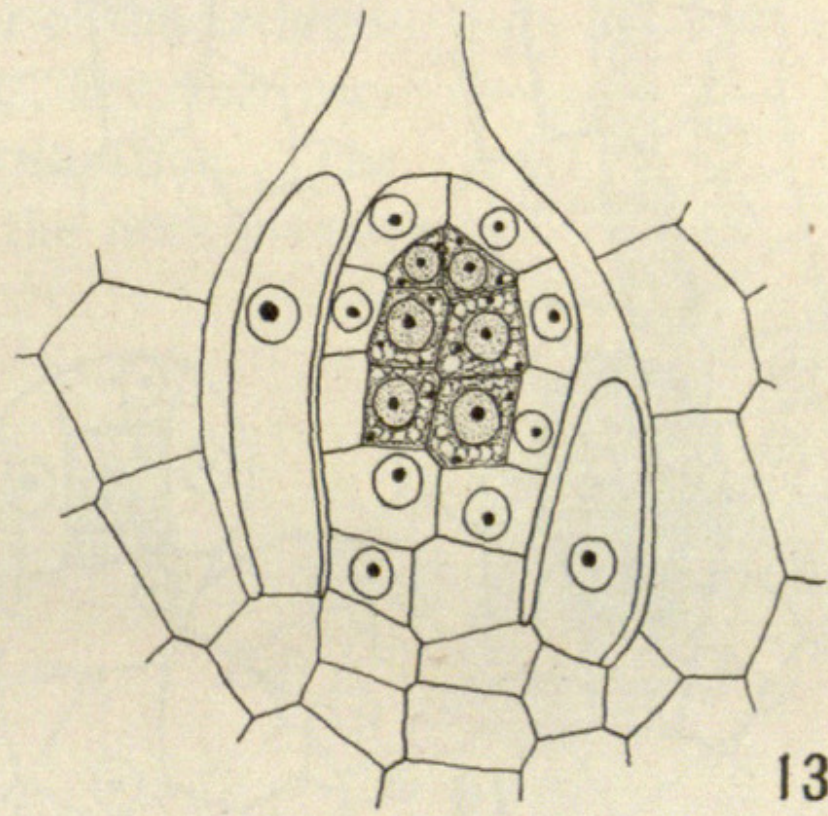

FIG. 13.-Completion of periclinal wall formation in young antheridium, $\times 790$. the same thallus, or, as Miss

STARR (8) has reported in Aytonia, an antheridial receptacle may follow the formation of an archegonial receptacle. Thus in these forms the archegonial receptacle represents a simple dorsal upgrowth of the thallus. In Fimbriaria and Grimaldia LeItgeb has shown that the apical cell is involved in the formation of the archegonial receptacle, and this is the situation in Reboulia. In the higher Marchantioideae this condition prevails, and further advance is shown merely by the greater production of archegonia over a longer period, and the formation of a long receptacle stalk earlier in the life history of the archegonia.

The archegonium initials arise from the third or fourth segment of each apical cell, and do not appear until the young receptacle is conspicuously dome-shaped. LEITGEB figures a very young 
receptacle bearing an archegonium in which the cover cell has been formed, but no such condition was observed by the writer in the material used in this study. The initial arises as a superficial cell which becomes papillate, and the first transverse wall cuts off a basal cell from an outer cell (figs. I4, I5). Three vertical walls then appear in the outer cell, and the primary axial cell and primary

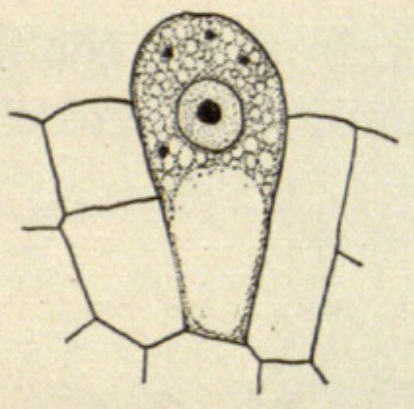

14
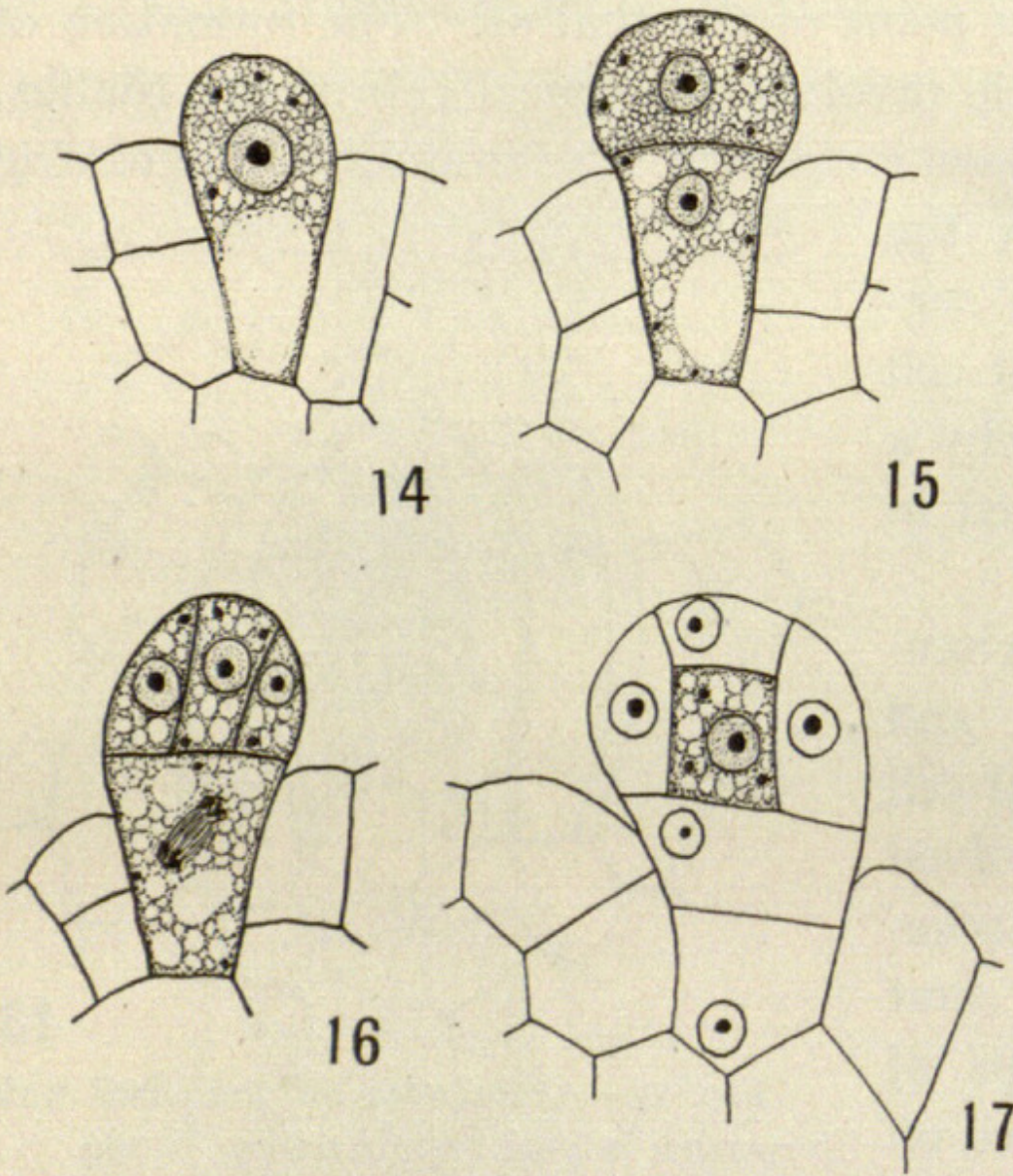

Figs. 14-17.-Fig. 14, archegonium initial, $\times$ 790; fig. 15, appearance of transverse wall cutting off basal cell from outer cell, $\times 79$ \% fig. I6, division of basal cell and differentiation of primary axial cell and primary wall cells, $X_{790}$; fig. 17 , differentiation of cover cell and central cell, $\times 79 \circ$.

may have mistaken an early division in the basal cell for one in the outer cell, as they show no mitotic figures which would prove the case. LEITGEB figures a young archegonium of Reboulia in which the 3 vertical walls have followed the transverse division of the archegonium initial, and DURAND observed the same condition in Marchantia polymorpha. Miss StarR's figures also indicate that the early development of the archegonium of Aytonia is like that of Reboulia. 
Further development of the archegonium is typical (figs. I $7^{-20}$ ). The cover cell divides by a vertical wall which accompanies the first division of the primary neck canal cell. No evidence was found to lead to the suspicion that earlier than this stage the cover cell contributes to the development of the neck cells. Numerous mitotic figures in the neck cells prove that they increase in number by intercalary divisions.

The ventral canal cell and egg are formed from the primary ventral cell rather early (fig. 20), and the former is unusually small. As soon as the egg is formed, the venter of the archegonium develops 2 layers of cells, and this condition prevails until after fertilization. The archegonial stalk is short, and the neck invari-
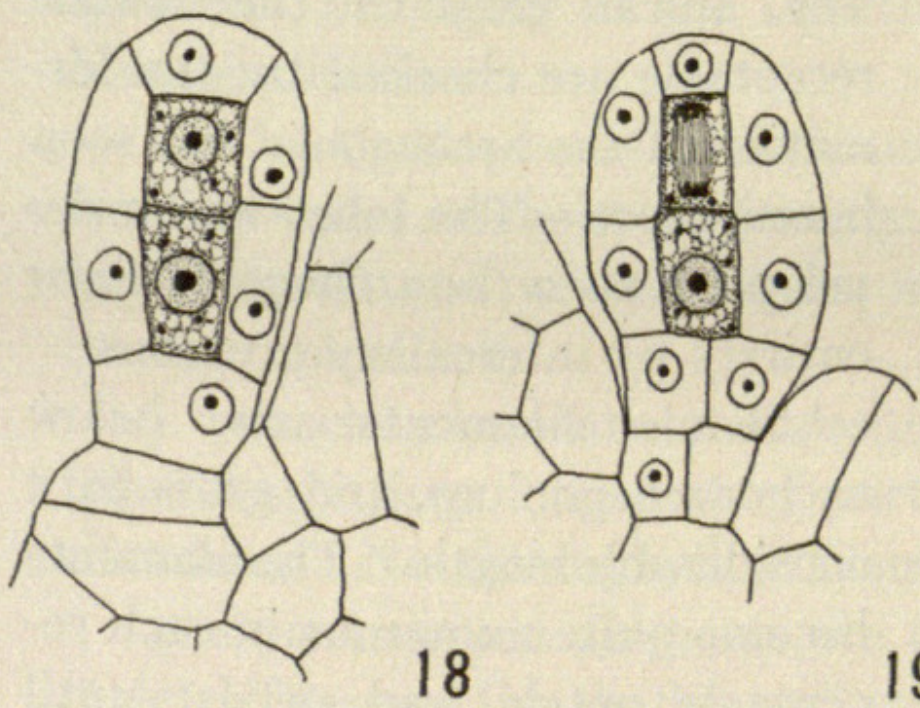

18

19

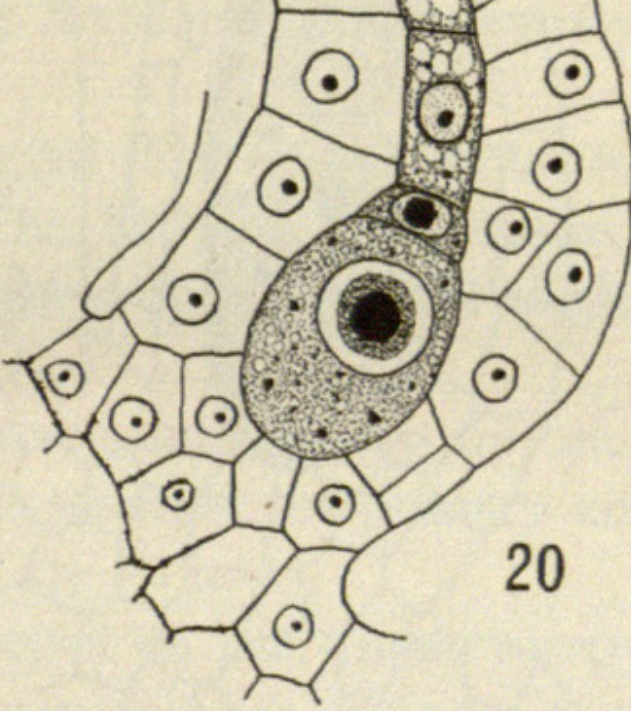

FIGS, I8-20.-Older archegonia: fig. I8, formation of primary neck canal cell and ventral cell from central cell, $\times 790$; fig. I9, division of primary ventral canal cell, $\times 790$; fig. 20 , older archegonium showing formation of ventral canal cell and egg, $\times 790$.

ably curves outward and upward (fig. 2I) so as to facilitate the entrance of the sperms, as in other forms in which the archegonia are borne similarly. The mature archegonium contains $18-20$ neck canal cells which break down soon after their formation. The neck in all cases shows 6 cells in cross-section, as among other Marchantiales. JANCZEWSKI states that the number of neck canal cells in Reboulia is 4 . He probably observed a nearly mature stage like fig. 20. 
In the great majority of cases only one archegonium is formed from a single segment of each apical cell, and usually the egg of each develops a sporophyte. In one case, however, 2 archegonia were observed which had developed from segments of the same apical cell. This indicates a reversion to a condition as seen in Marchantia, which from the standpoint of number of archegonia

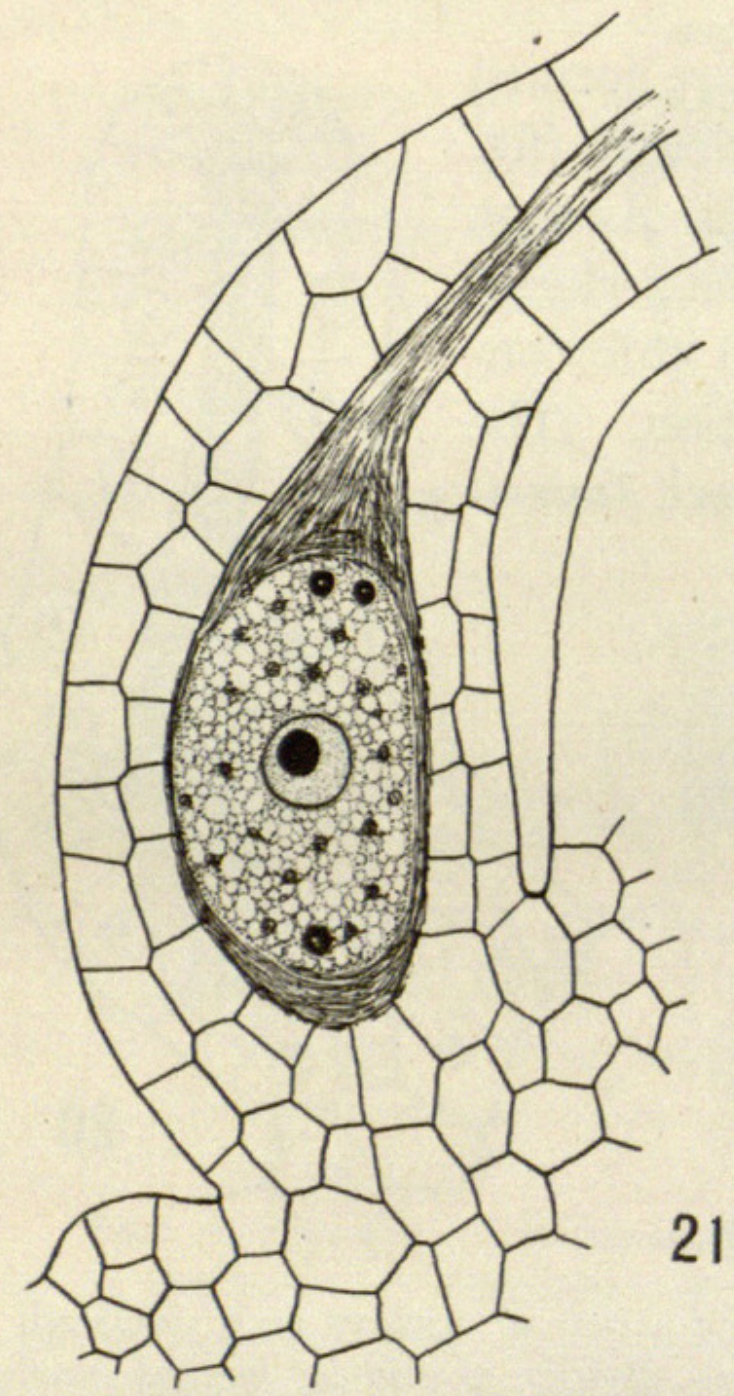

Fig. 21.-Venter of mature archegonium showing egg ready for fertilization, $\times 660$. is very primitive. The tendency to reduce the number of archegonia among the Marchantiales reaches its highest expression in forms like Reboulia. CAvers has also reported that in Reboulia occasionally 2 archegonia may be produced in the same receptacle notch. The apical cells of the female receptacle are checked by the formation of the archegonia and soon become lost. The lobes which develop between the archegonia grow entirely by intercalary divisions.

Slender filaments arise below each archegonium, and grow to a considerable length. The filaments become quite numerous in each receptacle notch, and persist until the spores are shed. They are probably protective in function. The mature egg is oval and contains many plastids and several large oil globules (fig. 2r). These oil drops are much larger than those found in the cells of the thallus, and they persist in the early stages of the embryo. The mature egg does not develop a cellulose wall until after fertilization.

The number of lobes developed by the mature female receptacle corresponds with the number of growing points organized in the young receptacle. The lobes are not conspicuous. In their paper $\mathrm{CH}$. and R. DouIN distinguish very carefully between the 
use of the terms "rays" and "lobes" as applied to the female receptacle of the Marchantiales, as follows:

Nous appellerons donc les rayons les divisions du capitule qui protègent les cavités pilifères, et nous réserverons le nom de lobes aux parties du capitule, qui recouvrent et protegent les involucres.

According to their interpretation and statements, neither rays nor lobes occur in Clevea, Sauteria, and Peltolepis; in some species of Marchantia and in all of the other genera of the order lobes only occur, while in most species of Marchantia true rays are formed. In Preissia both rays and lobes occur, but the rays are reduced, and the lobes very indistinct.

\section{Summary}

I. Reboulia comprises a single polymorphic species, R. hemisphaerica, belonging to the Operculatae division of the subfamily Marchantioideae.

2. The thallus bears smooth and pegged rhizoids and 2-ranked ventral scales without appendages. The body is differentiated into a dorsal and ventral region, and grows by means of a single cuneate apical cell.

3. Air chambers are abundantly formed and develop by centripetal splittings. Secondary partitions separate the primary air chambers. No chlorophyllose filaments are formed.

4. Barrel-shaped air pores are developed on the female receptacle. Those of the thallus and male receptacle are made up of a single layer of concentric cells.

5. Reboulia is monoecious (autoicous). The antheridial receptacle is sessile, and several may be produced during the growing season, but the formation of the archegonial receptacle terminates apical growth of the thallus and represents a definite branch system, as among the higher members of the order.

6. The antheridia develop like those of the other Marchantiales.

7. In the development of the archegonium the 3 vertical walls follow the appearance of a transverse wall in the initial cell, and further development is typical. Eighteen to 20 neck canal cells are formed, but only 4 are present at the time of division of the ventral cell. 
8. Several growing points are organized in the female receptacle from segments of the apical cell of the thallus, and each new apical cell comes to lie in a receptacle notch. Only I (rarely 2) archegonium is formed from the immediate segment of each apical cell.

The writer is very grateful to Dr. W. J. G. LAND for the material used in the investigation and for his encouragement and suggestions during the course of the study.

St. LaWrence University

Canton, N.Y.

\section{LITERATURE CITED}

I. Barnes, Charles R., and Land, W. J. G., Bryological papers. I. The origin of air chambers. Вот. GAZ. 44:97-186. I9го.

2. Cavers, F., The interrelationships of the Bryophyta. II. Marchantiales. New Phytol. 9:93-I12, I57-I86. I9ro.

3. Dourn, CH. and R., Le Reboulia Raddi. Rev. Gèn. Bot. 30: I29-145. I918.

4. Durand, E. J., The development of the sex organs and sporogonium of Marchantia polymorpha. Bull. Torr. Bot. Club 35:32I-335. I908.

5. JANCZEWSKI, ED. voN, Vergleichende Untersuchungen über die Entwicklungsgeschichte des Archegoniums. Bot. Zeit. 30:386-389. I872.

6. Leitgeb, H., Untersuchungen über die Lebermoose. 6. Die Marchantieen. Graz. I88r.

7. Schiffner, V., Hepaticae in Engler and Prantl's "Natürliche Pflanzenfamilien." $\mathrm{I}^{3}: \mathrm{I}-38$. I909.

8. Stark', Anna M., A Mexican Aytonia. Bot. Gaz. 6r:48-58. igr6.

9. Stephani, F., Species Hepaticarum. Bull. Herb. Boissier 6:790-799. I898.

I0. Strasburger, E., Die Geschlechtsorgane und die Befruchtung bei Marchantia polymorpha, L. Jahrb. Wiss. Bot. 7:409-422. I869-I870. 


\section{$2 \mathrm{BHL}$ Biodiversity Heritage Library}

Haupt, Arthur W . 1921. "Gametophyte and Sex Organs of Reboulia hemisphaerica." Botanical gazette 71(1), 61-74.

https://doi.org/10.1086/332789.

View This Item Online: https://www.biodiversitylibrary.org/item/109572

DOI: https://doi.org/10.1086/332789

Permalink: https://www.biodiversitylibrary.org/partpdf/224240

\section{Holding Institution}

Missouri Botanical Garden, Peter H. Raven Library

\section{Sponsored by}

Missouri Botanical Garden

\section{Copyright \& Reuse}

Copyright Status: Public domain. The BHL considers that this work is no longer under copyright protection.

This document was created from content at the Biodiversity Heritage Library, the world's largest open access digital library for biodiversity literature and archives. Visit BHL at https://www.biodiversitylibrary.org. 